\title{
Modeling, Evaluation, and Zoning of Marivan county Ecotourism Potential using Fuzzy Logic, FAHP, and TOPSIS
}

\author{
Jahanbakhsh Balist ${ }^{\mathrm{A}^{*}}$, Hamideh Heydarzadeh ${ }^{\mathrm{A}}$, Esmail Salehi ${ }^{\mathrm{A}}$ \\ Received: September 15, 2018 | Revised: December 14, 2018 | Accepted: February 26, 2019 \\ DOI: $10.5937 / g p 23-18879$
}

\begin{abstract}
Among all the diverse regions of Iran, Marivan is considered one of the touring poles in the country thanks to its unique views which play an important role in providing ecotourism potential. Currently, despite the importance of the issue, no specific study and planning have been done to locate proper zones for an outing. In this regard, evaluation of the land potential for any kind of activity such as recreational planning is the first step in planning. In this study, we evaluated and zoned the ecotourism potential of Marivan in Kurdistan province with fuzzy logic, FAHP, and TOPSIS, based on 15 criteria and applying GIS, where the outcome was zoning map of areas most suitable for ecotourism development. The results indicated that a total area of $3183 \mathrm{~km}^{2}$ (included in the study), classes 4 and 5 , respectively, with 151 and $513 \mathrm{~km}^{2}$ constitute the most appropriate zones for ecotourism development. Among points with ecotourism attraction, the Zarivar Lake claimed the top priority while Anjiran Heights received the last priority.
\end{abstract}

Keywords: Tourism; Marivan; Zoning; Fuzzy Logic; FAHP; TOPSIS

\section{Introduction}

Ecotourism has been categorized among new concepts which are still often misunderstood and not used correctly. Some misuse the term ecotourism to attract travelers who are aware of protecting practices of places which are only a natural location for tourism and believe in its social and environmental detrimental effects.

The term ecotourism was first introduced into tourism literature in 1980. The International Ecotourism Society presented the first comprehensive, valid and brief definition in 1990: "responsible for traveling to natural areas to protect the environment and improve the economic conditions of local communities". Concurrent with the acquisition of further knowledge and experience, the need for a complete and comprehensive definition increased. Marty Hani offered the newest and best and indeed a perfect definition: "Ecotourism is traveling to sensitive, unique, intact, and usually protected areas".

Ecotourism is an instructive trip for tourists, the revenue of which is spent on protecting the location which directly affects the economic development and political empowerment of local communities and honors different cultures and human rights (Drums \& Moore, 2009). Ecotourism is a sustainable form of natural environment-based tourism which primarily focuses on the knowledge about the natural environment and is managed in a way to have few harmful effects. This type of tourism occurs only in natural areas and plays a positive role in protecting these places (Fennell, 2003). Indeed, ecotourism is a new concept in tourism engendered initially by the idea of re-harmo-

\footnotetext{
A University of Tehran, Department of environmental planning, Environmental planning, Tehran, Iran

* Corresponding author: Jahanbakhsh Balist, j.balist@ut.ac.ir
} 
ny with the true nature and was raised by natural tourism community as responsible travel to natural areas that will be along protection of the environment and strengthening the local community welfare (Thampi, 2005). Ecotourism emphasizes the protection of natural resources and biological differences in the development of tourism. It also needs the appropriate support of resources utilized; in other words when the benefits of regional tourism resources are replaced with economic and industry benefits, then we should strive to support the appropriate development of natural and socio-cultural environment (Bin et al., 2008). It can be courageously argued that at present tourism is one of the main trade-economic pillars of the world, and its socio-economic impacts will lead to increased nation$\mathrm{al}$ and regional revenues, prosperity of different economic sectors, regional development (development of communication networks), and the development of social relations (Hall \& Page, 2002). Nowadays, considering the high remunerative level of tourism, many countries are prompted to invest heavily in this sector (Tremblay, 2006). In late 1980, when the term ecotourism entered English literature, few people could predict its prominent position approximately twenty years later as a trend in the tourism industry. It was due to this importance that the year 2002 was introduced by the United Nations as the Year of Ecotourism (Weaver \& Lawton, 2007). Tourism development is important for developing countries facing problems like high unemployment, limited currency, and single-product economy. On the other hand, the necessity to pay serious attention to the issue of travel and tourism as a new phenomenon in the mechanical life of the twenty-first century is an apparent necessity, and its importance is increasing progressively in the world (Butler, 2002). Tourism is the third largest industry in the twenty-first century which will undoubtedly be the most beneficial trade in the upcoming years of the twenty-first century (Fennell, 2003). A study conducted by Tourism Organization revealed that $\$ 1$ direct income of tourism will find a ratio of 4.3 value concerning the industry (Bin et al., 2008). Employment increased by tourism will add five job opportunities. Regarding the high remunerative level of tourism, many countries are prompted to investigate heavily in this sector (Tremblay, 2006). Ecotourism is a relatively new phenomenon in the tourism industry which constitutes only a part of the industry (Nyaupane \& Thapa, 2004). Without careful planning and attention to the ecological, local, cultural, and social capabilities, the tourism industry will face some problems for any region. On the other hand, a planned and perfect tourism system will encourage the proper use of the environment and different environmental, cultural, historical etc. (Edgell et al., 2008) resources in the region. In this field, tourism activity that is ideally planned can offer both optimal protection and management of nature and present other benefits for local communities and local economies (Salam et al, 2000). Even tourism can be considered as a means of creating empathy and international understanding-realization of world peace (Brown, 200o). On the one hand, the volatility and the negative effects of tourism in mass tourism are far more than those of other types of tourism, and in contrast, ecotourism is more in line with sustainability requirements than other types of tourism (Wearing \& Neil, 1999). One of the main strategies to minimize the negative impacts and to enhance positive impacts of ecotourism in geographical territories is planning to use land considering the capacities and natural potentials for ecotourism as well as a targeted selection of geographical districts to implement programs matching ecotourism. Consequently, evaluating ecotourism potentials of geographical ecotourism is an important step before tourism planning (Gthin$\mathrm{ji}$, 2006). In case the above measures take into account all aspects of sustainable development, then they can be considered one of the main strategies of sustainable development in tourism destinations. Ecotourism planning with the aim of serving the tourists interested in nature as well as preserving the natural environment is a "win-win" strategy which in any case benefits both the host and the guest (Ramsey \& Schaumleffel, 2006). Due to the increasing pressure of human population on natural resources, limited natural resources for recreation, lack of appropriate ecotourism projects, and lack of proper planning, thus ecotourists cannot take advantage of many attractions of nature. On the other hand, the imbalance in population density and natural resources has destroyed some areas. Thus, recreational planning in this kind of tourism is first considered a means of promoting social and economic levels. Also, thanks to protective functions, outdoor recreation as an experienced management strategy in areas were natural resources are located also provides their dynamic protection (Laurance et al., 2005).

Variable uncertainty and long periods in environmental planning make decision-making more complicated. MCDM methods cannot meet all these challenges. This method is an appropriate decisionmaking framework for local planning as it considers contradictory, ambiguous, multifaceted, and incomparable goals (Ananda \& Herath, 2008). The fuzzy logic which was raised against classical logic is considered as a powerful means for solving issues related to complex systems in which there are problems or issues related to reasoning, decision-making, and human deduction (Kourehpazan Dezfooli, 2008). Real phenomena are not only black or only white, but somewhat gray. Real phenomena are always fuzzy, vague, 
and imprecise (Azar \& Faraji, 2008). The range of classic membership functions $(\mathrm{xA}(\mathrm{x}))$ is a two-membered set of one and zero, while the range of fuzzy membership function $(\mu \mathrm{A}(\mathrm{x}))$ is a closed frame of zero and one (Kourehpazan Dezfooli, 2008). In FAHP method, fuzzy numbers are used for paired comparison of options, and the geometric mean method is used to obtain weights and advantages as it is easily generalized into fuzzy state and determines a unique answer for paired comparison matrix. In this way, the decision maker can express the paired comparisons of elements of each level in the form of trapezoidal fuzzy numbers (Elsavi et al., 2012).

The fuzzy logic as an optimized method is considered as a strong tool to solve issues of complex systems which are difficult to understand (Kourehpazan Dezfooli, 2008). In this study, the fuzzy AHP method is introduced and used as one of the criteria weighting methods in zoning discussions. This is one of the most widely used methods in decision-making (Keshavarz et al., 2014). In multi-criteria decision-making, incorporating GIS and MCDM capabilities is of key importance (Phua \& Minowa, 2005).

Integration of GIS with FAHP has many advantages in terms of locating, zoning, and environmental evaluation, through which we can use appropriate areas to establish a variety of activities in the fields of agriculture, natural resources, environment, land capability evaluation, etc (Faraji Sabokbar, 2005). In the present article, as the subject is spatial, we can use spatial-location decision-making planning models and methods. In discrete spatial models, the options are clear, and one or more options are chosen from among the options (Minciardi et al., 2008; Lu \& Ruan, 2007). For this purpose, a set of metrics and criteria are selected and then using special methods such as AHP, the ranking potential is valued and then combined via multi-attribute techniques such as TOPSIS, after which the best option is determined from among the options (Pourtaheri, 2011). TOPSIS technique is one of the most robust methods in Multiple Criteria Decision Making (Lin, 2010) which is considered a simple yet effective way of prioritization (Opricovic \& Tzeng, 2004). The logic underlying the TOPSIS method (Preferred prioritizing approach based on similarity to the ideal response), is defininign the ideal positive and ideal negative (Wang, 2008) solutions, and is on the basis that the selected option has the shortest route to an ideal solution. The positive and negative ideal solution is a hypothetical solution in which all index values are similar to maximum and minimum index values in the database (Rao \& Davim, 2008). In summary, the positive ideal solution is a combination of the best values available to the criteria, while the negative ideal solution includes the worst values available to the criteria (Wang, 2008).

\section{Research literature}

Some studies have been conducted in the field of tourism and ecotourism activities and zoning which are mentioned in this part of the study:

Banerjee et al. (2002) conducted a study for India entitled planning ecotourism for Midnapore West in India. In this study, GIS was used to identify the natural and cultural attractions and plan for ecotourism. In that study, first the region was derived from satellite images, and the data layers required were prepared, and ultimately, the region's ecotourism potential map was obtained based on the integration of land use, vegetation, soil fertility, and descriptive ecological characteristics (Banerjee et al., 2002). Gül et al. (2006) determined the potential of the region for outdoor recreation in the Natural Park of Turkey's Gül Chowk (Gül et al., 2006). Fung and Wong in 2007 planned macro-ecotourism in the international city of Hong Kong using multivariate evaluation in a GIS environment. They identified and introduced susceptible areas for ecotourism in the region by integrating various layers associated with ecotourism in the GIS software environment and satellite images. Ultimately, they stated the goal of their work as the development of ecotour- ism besides sustainable development (Fung \& Wong, 2007). Tsaur and Wang (2007) in a study first collected factors of sustainable tourism development (STD) for Green Island in Taiwan and then presented factors or final indices for valuation of STD regarding the characteristics of the study area using Delphi technique. In the next stage, criteria weights were calculated by the AHP process. Eventually, the performance measurement of each factor or criteria was extracted under the establishment of fuzzy sets. The results revealed that the region under study still needs more work to achieve the goals of tourism (Tsaur \& Wang, 2007). Li in 2008 studied sustainable tourism in China and introduced geo-tourism as an integral part of the thirdgeneration industries. This, in turn, triggers other industries such as transportation, food catering services, hotels, and tour operator agencies which will play an important role in sustainable development of the economy (Li, 2008). Parolo et al. (2009), in a study entitled optimizing the tourism impacts in the protected area by means of genetic algorithm for the growth and development of tourism in the Alps, investigated 18 criteria under measurement for the development, and 
using GIS and genetic algorithm, tried to optimize infrastructure development using logic criteria (Parolo et al, 2009). Kumari et al. (2010) conducted a study for a district in the West of Sikkim state in India. In this study, they used several indices such as the distribution of wildlife, ecology, ecological diversity, and flexibility characteristics of the environment. In addition to integrating the required layers in the GIS environment by means of AHP method, they also evaluated the ecotourism potentials in this region and specified the proper potentials at 4 levels of very high, high, moderate, and low (Kumari et al, 2010). Atasoy (2010) in Turkey studied tourism with GIS tools and concluded that the importance of GIS and its application in tourism is progressively increasing and with this technology, we can control tourism (Atasoy, 2010). Stankov et al. (2011), in an ecotourism article, offered a propos- al for focused tourism development in Stara Planina Park. They investigated ecotourism sites and alongside introducing the attractions, addressed the issue that expansion of ecotourism infrastructures endangers the region (Stankov et al., 2011). Bunruamkaew and Murayama (2011), in an article entitled locating ecotourism in the National Park of Thailand, assessed six indices and eight criteria using GIS and AHP and extracted the best place to develop ecotourism (Bunruamkaew \& Murayama, 2011).

Several studies have also been performed in Iran. For example, Miri (2011) evaluated Ouramanat tourism using TOPSIS model for rural areas in Paveh town. The results showed that the rural areas of Paveh are of great tourism potential (Miri, 2011). Amadi and Mozaffari (2012) in their study entitled analysis of proper zones for ecotourism development in Zanjan province

Table 1. Literature review

\begin{tabular}{|c|c|c|c|c|}
\hline Paper title & Year & Author & Used methods & Criteria \\
\hline $\begin{array}{l}\text { Multicriteria Evaluation } \\
\text { of Tourism Potential in } \\
\text { the Central Highlands } \\
\text { of Vietnam: Combining } \\
\text { Geographic Information } \\
\text { System (GIS), Analytic } \\
\text { Hierarchy Process (AHP) } \\
\text { and Principal Component } \\
\text { Analysis (PCA) }\end{array}$ & 2018 & $\begin{array}{l}\text { Hoang, H., } \\
\text { Truong, Q., } \\
\text { Nguyen, A., \& } \\
\text { Hens, L. }\end{array}$ & $\begin{array}{l}\text { GIS-based: cost } \\
\text { distance analysis } \\
\text { (AHP): determine } \\
\text { a weight for each } \\
\text { criterion } \\
\text { (PCA): combine the } \\
\text { internal and external } \\
\text { tourism potentials of } \\
\text { the considered sites. }\end{array}$ & $\begin{array}{l}\text { travel time, road and transportation networks, Aesthetic } \\
\text { and art value, Entertainment value, Cultural-historical } \\
\text { value, Scientific value, Biodiversity, The size of tourism } \\
\text { destination, Tourism seasonality, Linkages with other } \\
\text { tourist sites, Potential accessibility, The distance from } \\
\text { tourist attractions to the city center, Accommodation } \\
\text { quality, Catering quality, Service labor quality }\end{array}$ \\
\hline $\begin{array}{l}\text { GIS-based multicriteria } \\
\text { evaluation approach } \\
\text { in planning tourism } \\
\text { development sites in } \\
\text { environmentally sensitive } \\
\text { areas }\end{array}$ & 2016 & $\begin{array}{l}\text { Harun, N., \& } \\
\text { Samat, N. }\end{array}$ & $\begin{array}{l}\text { GIS-based: spatial } \\
\text { layer (AHP): } \\
\text { determine a } \\
\text { weighting coefficient } \\
\text { for each criterion }\end{array}$ & $\begin{array}{l}\text { coastline, topography, natural resources and forest, and } \\
\text { tourism sites }\end{array}$ \\
\hline $\begin{array}{l}\text { Coastal and marine } \\
\text { tourism: A challenging } \\
\text { factor in Marine Spatial } \\
\text { Planning }\end{array}$ & 2016 & $\begin{array}{l}\text { Papageorgiou, } \\
\text { M. }\end{array}$ & GIS & $\begin{array}{l}\text { environmental conditions for the tourism industry, the } \\
\text { quality of marine landscapes and other resources of } \\
\text { tourism, adaptation to climate change effects, spatial } \\
\text { regulations and, wise allocation of human uses in the } \\
\text { coastal zone }\end{array}$ \\
\hline $\begin{array}{l}\text { Planning of rural housings } \\
\text { in reservoir areas under } \\
\text { (mass) tourism based on a } \\
\text { fuzzy DEMATEL-GIS/MCDA } \\
\text { hybrid and participatory } \\
\text { method for Alange, Spain }\end{array}$ & 2016 & $\begin{array}{l}\text { Jeong, J. S., } \\
\text { García-Moruno, } \\
\text { L., Hernandez- } \\
\text { Blanco, J., \& } \\
\text { Sanchez-Rios, } \\
\text { A. }\end{array}$ & $\begin{array}{l}\text { (GIS) } \\
\text { Fuzzy DEMATEL }\end{array}$ & $\begin{array}{l}\text { Aspect, Slope, Elevation, Visibility, Temperature, } \\
\text { Precipitation, Geology and Soil, Land use, Ecosystems, } \\
\text { Vegetation type, Water source, Surface water, Site access, } \\
\text { Settlement, Population, Tourist site }\end{array}$ \\
\hline $\begin{array}{l}\text { Evaluating the recreation } \\
\text { potential of Ilgaz Mountain } \\
\text { National Park in Turkey }\end{array}$ & 2016 & $\begin{array}{l}\text { Cetin, M., \& } \\
\text { Sevik, H. }\end{array}$ & GIS analysis & $\begin{array}{l}\text { Landscape value (Size of the area, Surface condition, Flora, } \\
\text { Seas, lakes, streams, Visual quality, Caves, waterfall, } \\
\text { historical and cultural textures), Climate value (Temperature, } \\
\text { Precipitation, Sunshine, Windiness) Accessibility (The } \\
\text { region's touristic importance, Having a city with min. } \\
100,000 \text { of the population in the area, Access time from the } \\
\text { least } 5000 \text { populated area, Transportation except taxi and } \\
\text { private car, Convenience of transportation), Recreational } \\
\text { facility (Picnic facilities, Water condition, Overnight facilities, } \\
\text { Toilets, Parking areas, Casino, buffet, Guard and workers) } \\
\text { Negative factors (Air pollution, Insecurity, Water pollution, } \\
\text { Neglected, Noise), Recreation potential }\end{array}$ \\
\hline $\begin{array}{l}\text { Assessing land-use } \\
\text { changes in tourism area on } \\
\text { the example of Čajetina } \\
\text { municipality }\end{array}$ & 2016 & $\begin{array}{l}\text { Stankov, U., } \\
\text { Klaučo, M., } \\
\text { Dragićević, V., } \\
\text { Vujičić, M. D., \& } \\
\text { Solarević, M. }\end{array}$ & $\begin{array}{l}\text { effects of } \\
\text { development on } \\
\text { land-use changes in } \\
\text { tourism destination }\end{array}$ & $\begin{array}{l}\text { geographical data, geographical information systems, and } \\
\text { landscape metrics }\end{array}$ \\
\hline
\end{tabular}


using GIS, investigated the potential of proper zones for ecotourism. The results suggested that more than $30 \%$ of the total area of the province has a good potential for a variety of ecotourism activities (Amadi \& Mozaffari, 2012). Eftekhari et al. in 2013, used integrative MCDM and GIS method in identifying rural areas with ecotourism potential in touristic valley rivers in Tehran province. The results obtained indicated that the selected six villages correspond to the range of the four environmental areas and the model has a high capability in selecting exemplary valley river ecotourism villages in the country (Eftekhari et al., 2013). Karami et al. (2014) evaluated the areas with ecotourism potential using Analytical Hierarchy Process (AHP) in Babolroud's watershed in Mazandaran. The results showed that $19.33 \%$ of the area has a high potential and $52.81 \%$ of the area has a good potential for ecotourism (Karami et al., 2014). Sharifi and Bastani in 2015 in a survey used fuzzy model for ecotourism zoning in Shiraz. The results revealed that $12.56 \%$ of the total area of Shiraz has a very low potential for ecotourism activities (Sharifi \& Bastani, 2015). Maghsoudi et al. in 2015 began to locate optimal areas for ecotourism development in Kavir National Park using GIS and genetic algorithms. The results showed that Bahram Palace area is the best spot in Kavir National Park concerning ecotourism development (Maghsoudi et al., 2015).
In many studies, in the literature section of the study, similar techniques and techniques were used to identify and evaluate the tourism potential of a region. For example, Wang did this on a city-wide scale in 2007, using a combination of layers related to ecotourism and satellite imagery to identify areas with potential for tourism. Parolo et al. performed this in India in 2009. They used layers such as wildlife, ecology, and environmental resilience, in the GIS environment and using the AHP to determine the ecotourism capacity of the area in India (table. 1).

Given the importance of ecotourism planning in enhancing the cultural, social, and economic levels as well as conservation of natural resources and thus achieving sustainable development, in this study, using GIS and FAHP and TOPSIS techniques we have zoned the ecotourism potential of Marivan in Kurdistan province, which is one of the most beautiful regions of the country and still no study has been done in it to identify areas with ecotourism potential. The main question in this article is whether a GIS-based approach, combined with multi-criteria decisionmaking methods, could be used to assess the potential of a particular area for one type of use, which is natural tourism here, and whether the results correspond to ground facts. Can the results of these modeling be used in decision-making and planning?

\section{Materials and Methods}

\section{Area of Study}

Marivan with an area of $3196 \mathrm{~km}^{2}$ is one of the six cities within the political walls of Kurdistan province in West of Iran (Figure 1). Thanks to having diverse natural areas with pristine attractions, it is regarded as one of the most important areas for ecotourism in the country. Further, because of its proximity to $\mathrm{Su}-$

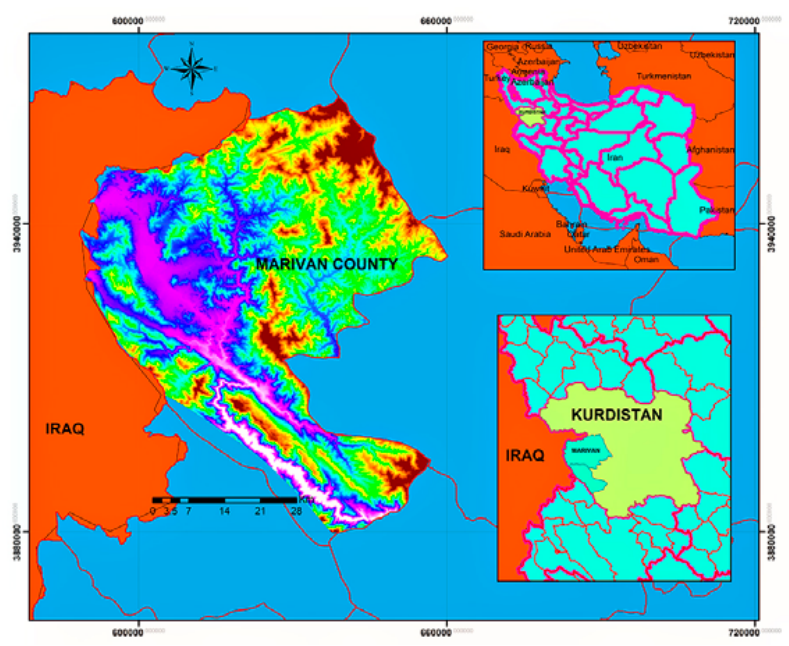

Figure 1. Location of the study area (Marivan in Kurdistan) laymaniyah, Iraq, and having a $100 \mathrm{~km}$ common border, the above area is considered as an important border area in the country. The mountain range of Zagros surrounds the city and its average height is $1,320 \mathrm{~m}$ above sea level (Badri et al., 2011). Marivan city with lots of natural attractions is one of the most beautiful regions of Kurdistan and West of the country. These attractions include Zarivar Lake, Zarivar beach park complex, Biloo plain, Ghomchian, Navtagh, and Mollaghoubi (Badri et al., 2011):

\section{Method}

Identification of different capacities at the micro-level of geographical space is the focus of development planners. Various technical, financial, time, etc. constraints make it impossible to develop capacity at the local level within a short time. Therefore, it is essential to utilize appropriate methods to determine the best location via defined criteria and indices. One of the existing potentials is tourism development capacities especially in ecotourism branch (Eftekhari et al., 2013).

In this study, the following procedure was performed in three stages after investigating different sci- 


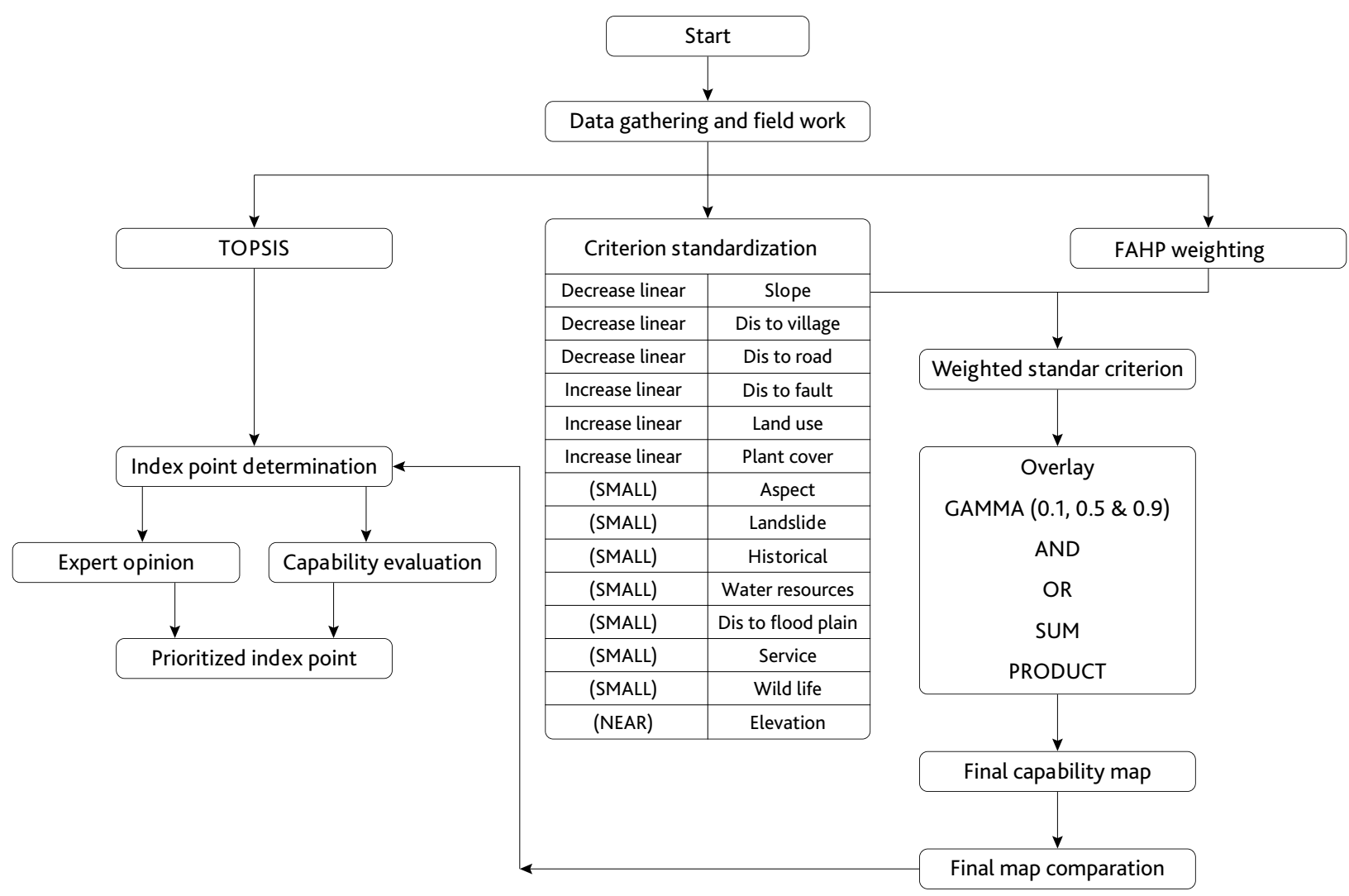

Figure 2. The process of modeling evaluation and potential ecotourism zoning with fuzzy logic, FAHP, and TOPSIS

entific sources. In the first stage, the effective criteria were weighted using FAHP techniques. In the second stage, the layers were turned into fuzzy layers using fuzzy functions and combined.

Finally, in the last stage using TOPSIS technique, the index points were prioritized according to expert opinions and the position of the studied point on the final map. Figure 2 demonstrates the process of producing evaluation map and ecotourism potential zoning with fuzzy logic, FAHP, and TOPSIS. In the following, a brief description of each of these methods is given.

The following table show the used GIS data in modeling process (table 2).

Table 2. The used data in research

\begin{tabular}{|c|c|c|c|c|}
\hline Data & Source & Scale & Reference & Explain \\
\hline slope & Digital elevation model & 30 meters & Jeong et al., 2016 & $\begin{array}{l}\text { If the slope increases, then the } \\
\text { suitability decreases. }\end{array}$ \\
\hline $\begin{array}{l}\text { distance to the } \\
\text { village }\end{array}$ & $\begin{array}{l}\text { Village point shapefile } \\
\text { by national geography } \\
\text { organization of IRAN }\end{array}$ & 250000 & $\begin{array}{l}\text { Huong T.T. et al., } \\
\text { 2018- Cetin \& } \\
\text { Sevik, } 2016\end{array}$ & $\begin{array}{l}\text { Proximity to villages can have a decisive } \\
\text { role in ecotourism. So, distance and } \\
\text { suitability are inversely related to each } \\
\text { other. }\end{array}$ \\
\hline $\begin{array}{l}\text { distance to a major } \\
\text { road }\end{array}$ & $\begin{array}{l}\text { Road line shapefile by } \\
\text { national geography } \\
\text { organization of IRAN }\end{array}$ & 250000 & $\begin{array}{l}\text { Huong T.T. et al., } \\
\text { 2018- Cetin \& } \\
\text { Sevik, } 2016\end{array}$ & $\begin{array}{l}\text { Roads provide access criteria, so } \\
\text { proximity to them is important. }\end{array}$ \\
\hline distance to fault & $\begin{array}{l}\text { Faultline shapefile by } \\
\text { national geology and mining } \\
\text { organization of IRAN }\end{array}$ & 250000 & $\begin{array}{l}\text { Cetin \& Sevik, } \\
2016\end{array}$ & $\begin{array}{l}\text { Faults can provide a kind of ecotourism } \\
\text { so that they can be a measure of } \\
\text { ecotourism. }\end{array}$ \\
\hline land use & $\begin{array}{l}\text { Land use polygon shapefile } \\
\text { by national geography } \\
\text { organization of IRAN }\end{array}$ & 250000 & Jeong et al., 2016 & $\begin{array}{l}\text { The type of land use is effective in } \\
\text { determining ecotourism potential, so it } \\
\text { ought to be investigated. }\end{array}$ \\
\hline plant cover & $\begin{array}{l}\text { Land cover polygon shapefile } \\
\text { by national geography } \\
\text { organization of IRAN }\end{array}$ & 250000 & Jeong et al., 2016 & $\begin{array}{l}\text { Vegetation is one of the factors in } \\
\text { ecotourism. Therefore, richer vegetation } \\
\text { contributes to stronger ecotourism. }\end{array}$ \\
\hline
\end{tabular}




\begin{tabular}{|c|c|c|c|c|c|}
\hline \multicolumn{2}{|l|}{ Data } & Source & Scale & Reference & Explain \\
\hline \multicolumn{2}{|c|}{ aspect } & Digital elevation model & 30 meters & Jeong et al., 2016 & $\begin{array}{l}\text { The direction of gradient has a direct } \\
\text { effect on the absorption of sunlight and } \\
\text { affects the vegetation, so it is best to be } \\
\text { investigated. }\end{array}$ \\
\hline \multicolumn{2}{|c|}{$\begin{array}{l}\text { distance to } \\
\text { landslide point }\end{array}$} & $\begin{array}{l}\text { landslide point shapefile } \\
\text { by national geography } \\
\text { organization of IRAN }\end{array}$ & 250000 & $\begin{array}{l}\text { Cetin \& Sevik, } \\
2016\end{array}$ & $\begin{array}{l}\text { Landslides are tourist attractions } \\
\text { and can be considered as ecotourist } \\
\text { destinations in a region. }\end{array}$ \\
\hline \multicolumn{2}{|c|}{$\begin{array}{l}\text { distance to tourism } \\
\text { attraction center }\end{array}$} & $\begin{array}{l}\text { Google earth digitization by } \\
\text { author }\end{array}$ & 250000 & $\begin{array}{l}\text { Huong T.T. et al., } \\
\text { 2018- Cetin \& } \\
\text { Sevik, } 2016\end{array}$ & $\begin{array}{l}\text { The proximity to natural and human- } \\
\text { made tourist attraction centers has a } \\
\text { significant influence on determining the } \\
\text { tourist potential of an area. }\end{array}$ \\
\hline \multirow{3}{*}{ 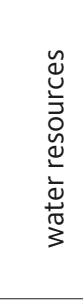 } & $\begin{array}{l}\text { Distance } \\
\text { to river }\end{array}$ & $\begin{array}{l}\text { river line shapefile by } \\
\text { national geography } \\
\text { organization of IRAN }\end{array}$ & 250000 & \multirow{4}{*}{$\begin{array}{l}\text { Jeong et al., } \\
\text { 2016- Cetin \& } \\
\text { Sevik, } 2016\end{array}$} & \multirow{4}{*}{$\begin{array}{l}\text { In general, water and water bodies are } \\
\text { attractive to tourists. The study of these } \\
\text { phenomena is essential for tourism } \\
\text { potential. }\end{array}$} \\
\hline & Dam & $\begin{array}{l}\text { Google earth digitization by } \\
\text { author }\end{array}$ & 250000 & & \\
\hline & Zarivar & $\begin{array}{l}\text { Google earth digitization by } \\
\text { author }\end{array}$ & 250000 & & \\
\hline \multicolumn{2}{|c|}{$\begin{array}{l}\text { distance to the } \\
\text { floodplain }\end{array}$} & $\begin{array}{l}\text { Floodplain line shapefile } \\
\text { by national geography } \\
\text { organization of IRAN }\end{array}$ & 250000 & & \\
\hline \multicolumn{2}{|c|}{ public services } & $\begin{array}{l}\text { Google earth digitization by } \\
\text { author }\end{array}$ & 250000 & $\begin{array}{l}\text { Huong T.T. et al., } \\
\text { 2018- Cetin \& } \\
\text { Sevik, } 2016\end{array}$ & $\begin{array}{l}\text { Public services play an important role in } \\
\text { tourism. The provision of services in an } \\
\text { area can affect the tourist attraction. }\end{array}$ \\
\hline \multicolumn{2}{|c|}{ wildlife } & $\begin{array}{l}\text { Department of the } \\
\text { environment of IRAN }\end{array}$ & 250000 & $\begin{array}{l}\text { Huong T.T. et al., } \\
\text { 2018- Cetin \& } \\
\text { Sevik, } 2016\end{array}$ & $\begin{array}{l}\text { Wildlife is one of the critical } \\
\text { characteristics of ecotourism. Richer } \\
\text { and more diverse the wildlife will attract } \\
\text { more tourists. }\end{array}$ \\
\hline \multicolumn{2}{|c|}{ elevation } & Digital elevation model & 30 meters & Jeong et al., 2016 & $\begin{array}{l}\text { Height is an element which influences } \\
\text { many characteristics of an area, so it is } \\
\text { best to be considered as a basic factor. }\end{array}$ \\
\hline
\end{tabular}

Fuzzy Analytic Hierarchy Process (Chang)

\section{Fuzzy Analytic Hierarchy Process (Chang)}

Saaty first presented analytic Hierarchy Process (AHP). It is a multi-criteria decision-making tool that is widely used in different areas. Since the introduction of AHP, it is used as a tool in the hands of decision-makers and researchers in multi-criteria decision-making, though the traditional AHP cannot still reflect the human mind. Traditional AHP is unable to express the exact value of the beliefs of the decision-maker in relation to different options (Moradzadeh et al., 2011). To solve the above problems, we use FAHP to determine the coefficients of the criteria. In this study, we use a FAHP which first introduced by Chang (Chang, 1996).

\section{Fuzzy membership functions}

A method for determining the weight of the desired criteria is using fuzzy membership functions in the Arc GIS 9.3 software. To fuzzify the criteria, fuzzy membership functions in Table 3 have been used. Using and applying any of these functions is performed according to two midpoints and spread parameters. Selection of the function for fuzzification occurs according to the nature, importance, and relationship

Table 3. The utilized fuzzy membership functions

\begin{tabular}{|l|l|}
\hline Linear & $\begin{array}{l}\text { This function defines fuzzy membership based on a maximum with fuzzy membership } 1 \text { and a minimum with fuzzy } \\
\text { membership 0 }\end{array}$ \\
\hline Near & $\begin{array}{l}\text { This function specifies the membership function based on a specific value by a defined midpoint by the user; the } \\
\text { midpoint takes membership 1 }\end{array}$ \\
\hline Small & $\begin{array}{l}\text { This function is used when small values in the map have a membership close to 1. This function is also defined based } \\
\text { on a midpoint defined by the user (mid-point membership is 0.5) }\end{array}$ \\
\hline
\end{tabular}


of each criterion with the purpose (Safari \& Akhdar, 2012).

\section{Fuzzy operators}

Types of fuzzy operators include: Fuzzy AND, Fuzzy OR, Fuzzy Algebraic Product, Fuzzy Algebraic Sum, and Gamma (Malek et al., 2011).

\section{Fuzzy AND}

It is defined as follows:

$$
\mu_{\text {Combination }}=\operatorname{MIN}\left(\mu_{A}, \mu_{B}, \mu_{C}, \ldots\right)
$$

In this relation, $\mu_{A}, \mu_{B}$, and $\mu_{C}$ reflect fuzzy membership values of extant pixels in a specified position on the maps of different factors.

\section{Fuzzy OR}

It is defined as follows:

$$
\mu_{\text {Combination }}=\operatorname{MAX}\left(\mu_{A}, \mu_{B}, \mu_{C}, \ldots\right)
$$

In this relation, $\mu_{A}, \mu_{B}$, and $\mu_{C}$ are defined similarly to fuzzy AND

Fuzzy Algebraic Product

It is defined as follows:

$$
\mu_{\text {Combination }}=\operatorname{MAX}\left(\mu_{A}, \mu_{B}, \mu_{C}, \ldots\right)
$$

Where, $\mu_{i}$ represents membership value in the $\mathrm{i}$-th factor map. Using this function, the fuzzy membership values declines in the output map and approaches zero. So, the combination of factors will have a reducing effect. In other words, factors weaken each other.

\section{Fuzzy Algebraic Sum}

It is defined as follows:

$$
\mu_{\text {Combination }}=1-\left(\coprod_{i=1}^{n}\left(1-\mu_{i}\right)\right)
$$

Where, the $\mu_{i}$ represents the membership value in i-th factor map. Using this function, fuzzy membership values in the output map grow and approach 1 which will have a potentiating effect due to a combination of factors. In other words, factors are mutually reinforcing each other.
Unlike the fuzzy AND and fuzzy OR, in Fuzzy Algebraic Product and Fuzzy Algebraic Sum, all membership values of input maps affect the output map.

\section{Gamma}

This operator of Fuzzy Algebraic Sum and Product is defined as follows:

$$
\mu \text { Combination }=(\text { Fuzzy Algebraic Sum }) \gamma
$$$$
\text { - (Fuzzy Algebraic Product) } 1-\gamma
$$

Where, the value of $\gamma$ is a number between zero and one. The correct and informed selection of $\gamma$ between zero and one produces values in the output indicating flexible compatibility between the descending trend of Fuzzy Algebraic Product and ascending trend of Fuzzy Algebraic Sum (Bonham-Carter, 1991).

\section{WLC technique}

The weighted linear combination method (WLC) is the most common technique for analyzing multiscale evaluations. This technique also is called a "scoring method". This method is based on the content of the weight average. The analyzer or decision-maker functions based on the "relative importance" weighted directly to the scales. Through multiplying the relative weight by the feature value, a final measure can be obtained for each option (such as picture element in the spatial analysis). After specifying the final value for each option, alternatives, which have higher values, will be the best option for the desired purpose (Malczewski, 1999). Determining the proportion for a specific operation or evaluating the potential of a particular occurrence is considered to be the desired purpose. In this method, decision-making principles calculate the value of each Ai options using Eq. (1):

$$
A i=\sum_{i=1}^{n} W j \cdot X i j
$$

In this equation, is the $\mathrm{j}$ criterion weight; represent a value accepting place about $j$ criterion. In other words, this value can indicate the appropriate degree of the I location about $\mathrm{j}$ criterion; $\mathrm{n}$ shows the total number of criteria, and $\mathrm{Ai}$ is a value, which will attach to the I location. In this method, the total weight should be equal to 1; otherwise, in the last stage, $\mathrm{Ai}$ should be divided by the total of all weights. Thus, the Ai output will be between o and 1. Higher or lower values of the output can be due to an appropriate or inappropriate option; weight normalization can be omitted. In the end, the ideal option will be the one with a higher value of $\mathrm{Ai}$ (Malczewski, 2004). 


\section{TOPSIS technique}

Topsis was presented by Hwang for the first time (Hwang \& Yoon, 1981). The advantage of this method is that we can simultaneously use both objective and subjective criteria and indices (Affisco \& Chanin, 1988). The only subjective data required by the TOPSIS method is the importance of criteria weights, which is the reason why this method is attractive for decision makers (Olson, 2004). Topsis concept expresses the notion that an ideal option is not the option with the shortest distance from the positive ideal solution; rather the ideal is the one with the farthest distance from the negative ideal solution (Deng et al., 200o). Therefore, the concept of Topsis needs to determine an ideal point.

In explaining the steps to solve Topsis, Tavana states that at the first step a decision-making matrix is built for $\mathrm{n}$ options and $\mathrm{m}$ criteria (Tavana \& Marbini, 2011).

\section{Results and Analysis}

In this study, first the data and the maps were collected, and a field visit was done in the area. In the next step, effective criteria in the evaluation process of the area were selected for ecotourism through revision based on the view of experts and reviewing the literature. Effective criteria included 15 man-made attractions criteria (distance from villages, Zarivar tourist complex, and distance from the tourist-attracting sites), natural attractions (fault, flood-prone areas, water resources including dams, rivers and lakes, covering animals, vegetation and landslides), service-welfare facilities (such as public services and distance from asphalt roads), land use and physiographics (slope and slope direction). The criteria maps were produced using existing data, fieldwork, satellite data, and in GIS. The homogeneous criteria in the entire area or those which did not exist were not included in the analysis. FAHP method was utilized to determine the weights of the criteria. Criteria matrix was first established. Then, the relative importance of all criteria was determined by specialists in FAHP format using paired comparison. For this purpose, the Delphi method was employed, and a questionnaire was developed in the form of FAHP. Through the questionnaire, the experts were asked to determine the relative importance of each criterion relative to other criteria. Finally, judgments were entered into the software environment, and the final weight of the criteria was determined, with the most important ones extracted. Finally, fuzzy priority map was prepared and classified, whereby the priority of the area was pinpointed for ecotourism.

\section{Fuzzy Hierarchical Model Using Chang's Method}

FAHP model was used to calculate the weights of criteria and sub-criteria. In this way, by gathering expert opinions, the value and importance of criteria were specified pairwise to each other, and pair comparison matrices of criteria were formed and eventually normalized weights were obtained according to Table 4. With regard to the investment and preparation of Zarivar coastal park complex, this lake is attractive in terms of being manmade. In other words, investments made in this place is perfect for attracting tourists. For this reason, this map has been considered in the modeling.

As seen in the table above, out of 15 intended criteria, Zarivar coastal park complex with a score of 0.244 has claimed the greatest weight, while the height above sea level showed the minimum weight.

At this stage data, layers were standardized and produced as the location for each criterion. To achieve this, functions designed in ARC GIS software were used. In other words, after separating and preparing the raw data layers of the study area, different layers were valued and standardized based on the functions of Table 3.

Three functions were used including Linear, Near and Small functions to standardize the criteria observed in Figure 3. The minimum and maximum values were assigned by the user according to the minimum and maximum values available in the spatial layer. In near and small functions also the midpoint and spread parameter were assigned by the user according to the values of the spatial layer. The type of function used to standardize the criteria was selected based on studies conducted and criteria properties corresponding the function formula. Reducing and increasing linear functions were used for criteria having to reduce and/or increasing properties associated with ecotourism. Also, Small and Near criteria were used for other functions. Considering the possibility of interpreting height from seeing a level correlation with ecotourism by Near function, the aforementioned function was used to measure the height. To obtain the final layer of zoning area, ArcGIS 9.3 software was used. The weight of the intended criteria was multiplied by the characteristics of individual parts of the area, and then all these layers were combined. Table 5 reports the fuzzification of effective criteria in evaluating and zoning the ecotourism potential.

Near function is shown in Figure A-3 in which the midpoint is the best point and rates 1 and different colors represent different values of the spread parameter. When we approach blue color, and away from green, it means that the value of spread parameter increas- 
Modeling, Evaluation, and Zoning of Marivan county

Ecotourism Potential using Fuzzy Logic, FAHP, and TOPSIS

Table 4. The weight of criteria and sub-criteria

\begin{tabular}{|c|c|c|c|c|}
\hline Criteria & Criteria weight & Sub-criteria & Sub-criteria weight & Criteria final weight \\
\hline \multirow{3}{*}{$\begin{array}{l}\text { Manmade } \\
\text { attraction }\end{array}$} & \multirow[t]{3}{*}{0.403} & Distance to the village & 0.122 & 0.049 \\
\hline & & Zarivar beach park & 0.558 & 0.224 \\
\hline & & Distance to tourism attraction center & 0.320 & 0.128 \\
\hline \multirow[t]{6}{*}{ Natural attraction } & \multirow[t]{6}{*}{0.292} & Distance to fault & 0.078 & 0.022 \\
\hline & & Distance to flood plain & 0.094 & 0.027 \\
\hline & & Water resources (dam, river, and lake) & 0.277 & 0.080 \\
\hline & & Wildlife & 0.268 & 0.078 \\
\hline & & Plant cover & 0.211 & 0.061 \\
\hline & & Distance to landslide point & 0.072 & 0.021 \\
\hline \multirow[t]{2}{*}{ Services } & \multirow[t]{2}{*}{0.138} & Public services & 0.667 & 0.092 \\
\hline & & Distance to a major road & 0.333 & 0.092 \\
\hline Land use & 0.108 & Land use & - & 0.108 \\
\hline \multirow[t]{3}{*}{ Physiography } & \multirow[t]{3}{*}{0.0620} & Slope & 0.540 & 0.033 \\
\hline & & Aspect & 0.297 & 0.018 \\
\hline & & Elevation & 0.163 & 0.010 \\
\hline Weight sum & 1 & & & 1 \\
\hline
\end{tabular}

Table 5. The function used for criteria fuzzification

\begin{tabular}{|c|c|c|c|c|c|}
\hline Row & \multicolumn{2}{|l|}{ Criteria } & Fuzzification function & Max & Min \\
\hline 1 & \multicolumn{2}{|l|}{ slope } & Decrease linear & 50 & 30 \\
\hline 2 & \multicolumn{2}{|c|}{ distance to the village } & Decrease linear & 2000 & 0 \\
\hline 3 & \multicolumn{2}{|c|}{ distance to a major road } & Decrease linear & 15000 & 500 \\
\hline 4 & \multicolumn{2}{|l|}{ distance to fault } & Increase linear & 2000 & 1000 \\
\hline 5 & \multicolumn{2}{|l|}{ land use } & Increase linear & 5 & 1 \\
\hline 6 & \multicolumn{2}{|l|}{ plant cover } & Increase linear & 5 & 1 \\
\hline Row & \multicolumn{2}{|l|}{ Criteria } & Fuzzification function & Midpoint & Spread \\
\hline 7 & \multicolumn{2}{|l|}{ aspect } & SMALL & 45 & 2 \\
\hline 8 & \multicolumn{2}{|c|}{ distance to landslide point } & SMALL & 3000 & 1 \\
\hline 9 & \multicolumn{2}{|c|}{ distance to tourism attraction center } & SMALL & 2000 & 1 \\
\hline \multirow[t]{3}{*}{10} & \multirow[t]{3}{*}{ water resources } & Distance to river & SMALL & 1000 & 5 \\
\hline & & Dam & SMALL & 3000 & 5 \\
\hline & & Zarivar & SMALL & 4000 & 5 \\
\hline 11 & \multicolumn{2}{|c|}{ distance to the floodplain } & SMALL & 500 & 1 \\
\hline 12 & \multicolumn{2}{|l|}{ public services } & SMALL & 2000 & 1 \\
\hline 13 & \multicolumn{2}{|l|}{ wildlife } & SMALL & 3000 & 1 \\
\hline 14 & \multicolumn{2}{|l|}{ elevation } & NEAR & 1600 & 0.001 \\
\hline
\end{tabular}
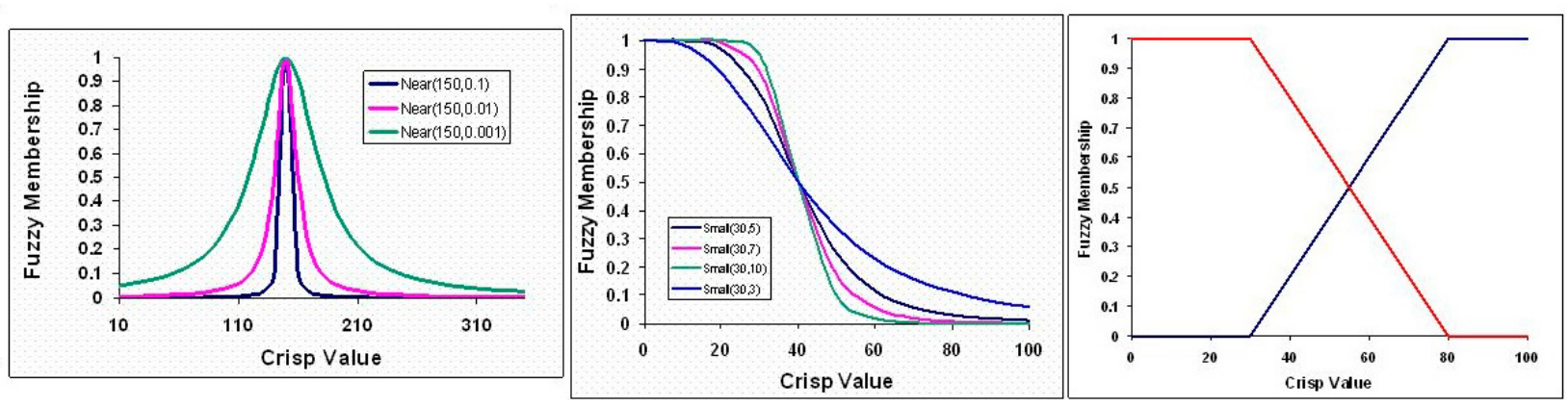

Figure 3. The figure of the function used for fuzzification of layers 

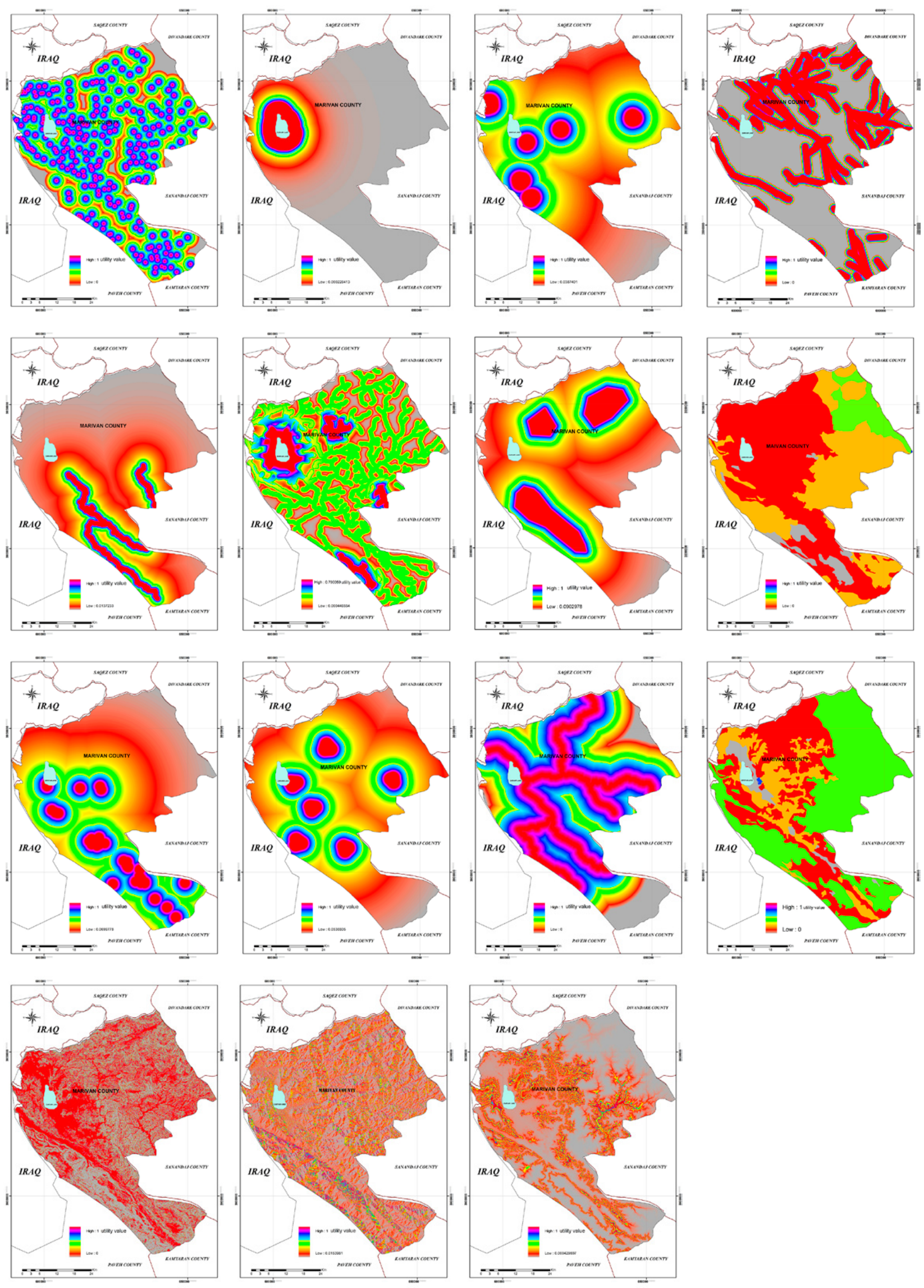

Figure 4. Standardized layer (A: dis to village- B: dis to Zariver lake- C: dis to tourism attraction centerD: dis to fault- E: dis to floodplain- F: water resources- G: Wildlife- $\mathrm{H}$ : plant cover-I: dis to landslide- J: public services$\mathrm{K}$ : dis to major road- L: land use- M: slope- N: aspect- O: elevation) 
es where the domain it encompasses shrinks. Green with value 0.1 includes the highest domain. This function can be used for criteria with a normal distribution which was used in this study to measure height. In Figure B-3, the Small function is shown which represents the midpoint. The turning point criteria and in this function the farther we move from the turning point. The size of changes varies in distance units based on spread parameters where the size of changes in green with a value of 10, per unit change in $\mathrm{X}$-axis is the most and in blue color with value 3 (in total values from 1 to 10) is the lowest. A Linear function is shown in Figure $\mathrm{C}-3$. This function is one of the most versatile and easiest standardizing functions and includes two types of reducing and increasing. Minimum and maximum values in this function are assigned based on the values of the spatial layer and the user's opinion.

In Figure 4, standardized layers by the above functions can be seen for the 15 criteria used. The values of each criterion are turned into a range between zero and one based on fuzzy logic.

\section{Combining Fuzzy Layers of the Criteria}

In this part of the article, the result of a combination of layers used by the WLC method and fuzzy operators described in the method part can be seen. Vari- ous fuzzy operators were used for spatial data layers. to integrate layers these operators were used based on the performance of each function. To achieve different results and to compare them to make the ultimately optimized combination in this study and future studies, the 15 criteria were integrated to evaluate the ecotourism potential with fuzzy gamma operators at three levels of 0.5, 0.1 and 0.9, SUM, PRODUCT, AND, OR, and linear weighted combination (Figure 5).

Figure 5 shows the final maps of potential ecotourism zoning by different operators, as well as the method of weighted linear combination classified in five classes (first map). The area of each of the classes is shown in Figure 6. If we compare the results of fuzzy operators with each other, we deduce that the performances of gamma function 0.1 and Product are similar, meaning that it selects the smallest values in the corresponding cells, and leaves a reducing effect. This fuzzy value approaches zero in these two operators. These operators are more practical, when environmental sensitivities are too high, or when restrictions are considered. In Fuzzy AND among the corresponding cells in different layers, the cells with the lowest value is chosen. The results of Fuzzy AND is similar to Gamma function 9.0. Gamma 9.o functions similarly to SUM meaning that the values ap-
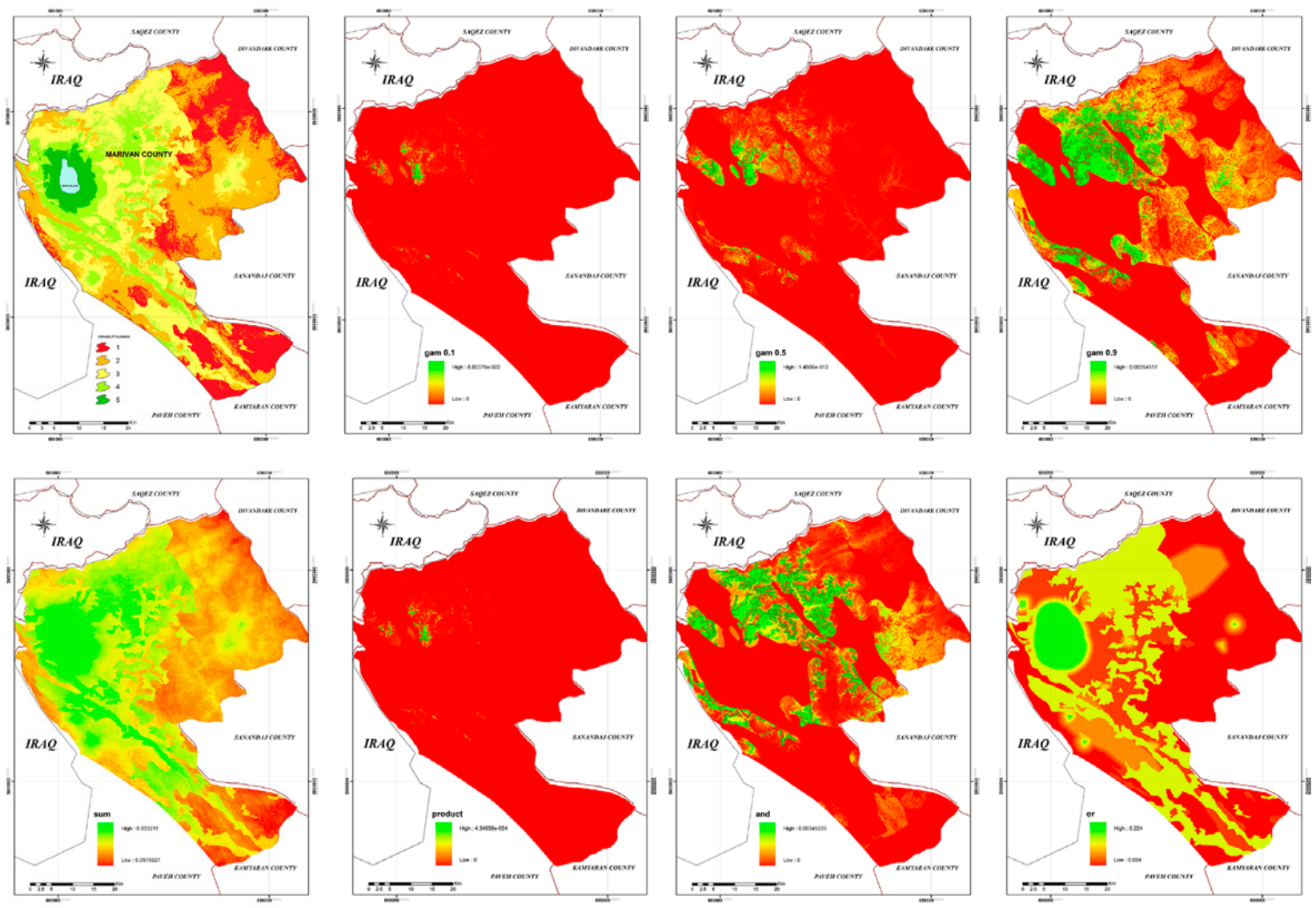

Figure 5. the final map of ecotourism capability by WLC method and fuzzy operator GAMMA at three levels $0.1,0.5$ and 0.9 , SUM, PRODUCT, AND \& OR 
Table 6. Zone area and percentage in different methods ( $A$ unit $=\mathrm{km}^{2}$ )

\begin{tabular}{|c|c|c|c|c|c|c|c|c|c|c|c|c|c|c|c|c|}
\hline & \multirow{2}{*}{\multicolumn{2}{|c|}{ WLC }} & \multirow{2}{*}{\multicolumn{2}{|c|}{ AND }} & \multirow{2}{*}{\multicolumn{2}{|c|}{ OR }} & \multicolumn{6}{|c|}{ GAMMA } & \multirow{2}{*}{\multicolumn{2}{|c|}{ SUM }} & \multirow{2}{*}{\multicolumn{2}{|c|}{ PRODUCT }} \\
\hline & & & & & & & \multicolumn{2}{|c|}{0.1} & \multicolumn{2}{|c|}{0.5} & \multicolumn{2}{|c|}{0.9} & & & & \\
\hline & A & $P$ & $A$ & $P$ & $A$ & $P$ & A & $P$ & A & $P$ & A & $P$ & A & $P$ & A & $P$ \\
\hline VERY LOW & 652 & 20 & 2545 & 77 & 2000 & 62 & 2750 & 86 & 2291 & 72 & 2091 & 65 & 591 & 18.5 & 2750 & 86 \\
\hline LOW & 972 & 30 & 409 & 12.8 & 1000 & 31 & 185 & 5 & 541 & 17 & 591 & 18.5 & 954 & 30 & 185 & 5 \\
\hline AVERAGE & 893 & 28 & 181 & 5.7 & 90 & 2.8 & 115 & 3.6 & 203 & 6.4 & 318 & 10 & 863 & 27 & 115 & 3.6 \\
\hline $\mathrm{HIGH}$ & 513 & 16 & 90 & 2.8 & 48 & 2.2 & 82 & 2.5 & 101 & 3.1 & 136 & 4.2 & 454 & 14 & 82 & 2.5 \\
\hline VERY HIGH & 151 & 4.7 & 45 & 1.4 & 45 & 2 & 51 & 1.6 & 47 & 1.5 & 45 & 1.4 & 334 & 10.5 & 51 & 1.6 \\
\hline
\end{tabular}

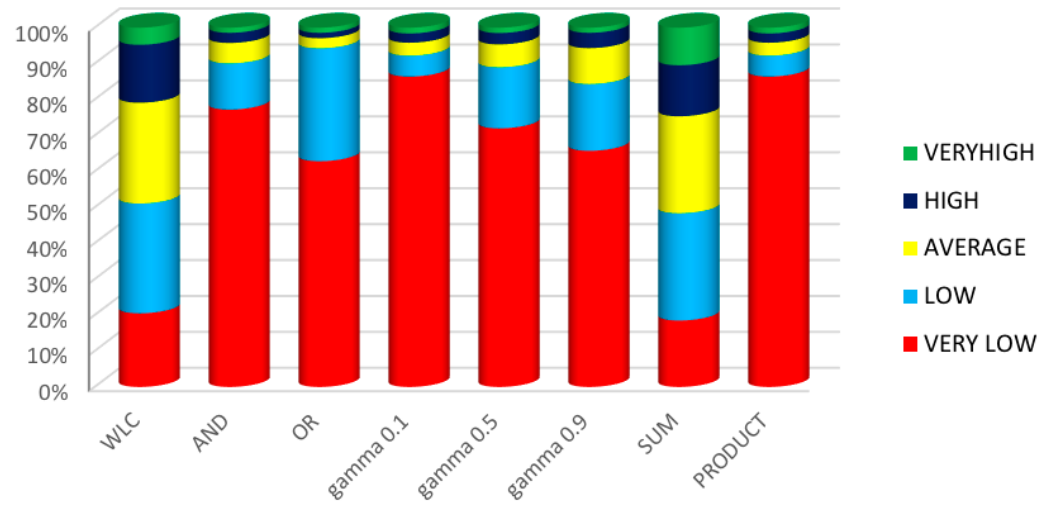

Figure 6. The area of each zone in different methods

proach 1 and the maximum values are selected. Fuzzy OR selects the highest values in the corresponding cells. Since in this study, the distance layer of Zarivar Lake has claimed the greatest weight, thus it has the greatest effect among layers, and as can be seen, the Zarivar location has been chosen as the best place for ecotourism. Gamma function 0.5 is the intermediate range between Fuzzy Algebraic Sum and Fuzzy Algebraic Product and is the intersection of the graphs of

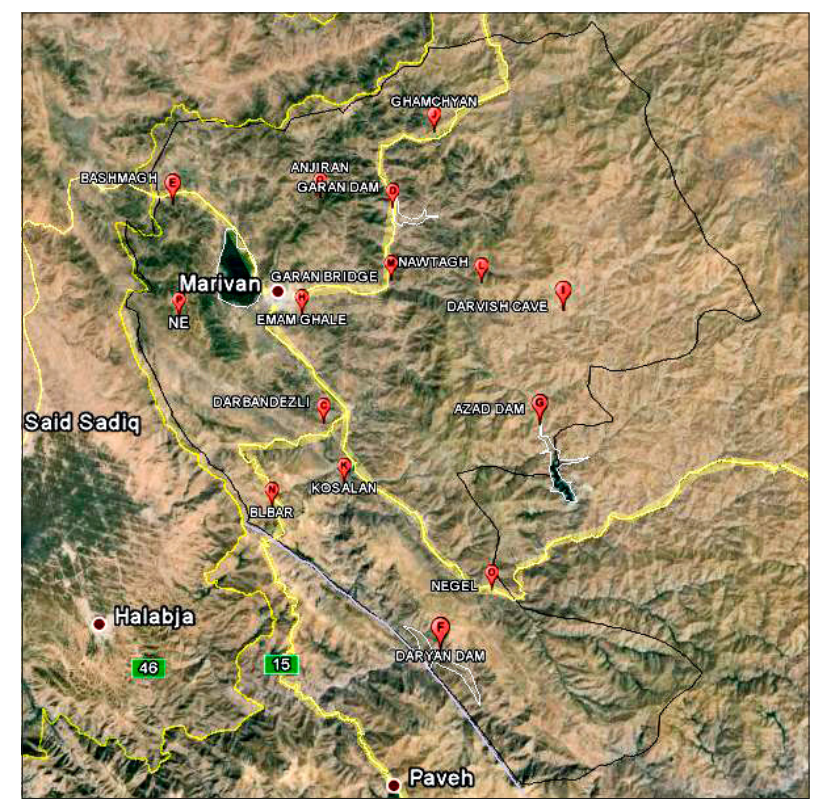

Figure 7. Ecotourism attraction location in Marivan County these two operators which in most cases provides the most logical and consistent results.

In Table 6, the potential is divided into five classes of very high, high, moderate, poor and very poor, and the percentage of each class and their area is also shown Figure 6 also represents the function of operators in evaluating the ecotourism potential. The weighted linear combination method is the multiplication of each of the layers by the weight coefficients obtained from decision-making technique and has many similarities with the SUM function. The results reveal that in Fuzzy Algebraic Sum and weighted linear combination, a larger area of the city has very high potential for ecotourism development. In this study, in addition to evaluating the potential of Marivan city for the ecotourism development, the integration of these methods is discussed for the optimized evaluation in future studies.

\section{TOPSIS Technique}

As mentioned in the theoretical foundations, in modeling evaluation and zoning the ecotourism potential, it is necessary to both determine the most useful criteria and the weight of each criterion, and employ appropriate prioritization techniques. For this purpose, seventeen ecotourism attractions of Marivan were selected (Figure 7), where the TOPSIS approach was implemented. Prioritization of index points was done according to the position of the point in the zone and expert opinion with coefficients of 0.65 and 0.35 , respectively. The results are provided in Table 7. 
Table 7. Ecotourism attraction ranking by TOPSIS

\begin{tabular}{|l|c|c|c|}
\hline Ecotourism attraction & $\begin{array}{c}\text { Weight based on } \\
\text { the capability }\end{array}$ & $\begin{array}{c}\text { Weight based on } \\
\text { the expert opinions }\end{array}$ & $\begin{array}{c}\text { the similarity } \\
\text { to the worst }\end{array}$ \\
\hline Zarivar lake & 5 & 10 & 1 \\
\hline Ovramanat & 3 & 9 & 0.71977 \\
\hline Darband Dezli & 4 & 8 & 0.6666 \\
\hline Garan dam & 4 & 7 & 0.6666 \\
\hline Bashmagh boundary & 4 & 7 & 0.6666 \\
\hline Daryan dam & 4 & 7 & 0.6666 \\
\hline Azad dam & 3 & 6 & 0.450623 \\
\hline Emam summit & 3 & 5 & 0.448842 \\
\hline Ghamchyan heights & 3 & 4 & 0.391221 \\
\hline Darvish cave & 2 & 3 & 0.383881 \\
\hline Kosalan heights & 4 & 3 & 0.333333 \\
\hline Nawtagh heights & 3 & 3 & 0.28023 \\
\hline Garan historical bridge & 3 & 3 & 0.28023 \\
\hline Bilbar village & 3 & 3 & 0.28023 \\
\hline Negel village & 3 & 2 & 0.238614 \\
\hline Ne' heights & 4 & 1 & 0.215173 \\
\hline Anjiran heights & 3 & 0.35 & 0.150544 \\
\hline Criteria type & 0.65 & & 1 \\
\hline Criteria weight & & 1 & \\
\hline
\end{tabular}

\section{Discussion and Conclusion}

Today, the tourism industry, especially eco-tourism, has found a special status, as a new approach for the development of coexistence of man and society, and for economic productivity in regional development. Hence, areas with natural landscapes create unique attractions thanks to geographical and environmental conditions in climatic, topographic, and hydrologic terms. Accordingly, attention to this nascent branch of tourism (ecotourism) is necessary in urban and suburban areas, as the extent ecotourism potential treasures can convert these areas into a tourism hub across the vast geographical territory. Indeed, through strengthening capacities, the ground for development of the tourism networks in the region is realized. By planning, this process-like view to ecotourism development becomes possible in Marivan. The tourism industry forms an integral part of the economy of many countries. Meanwhile, ecotourism as a natural part of this industry can play an important role in the economy. Areas with a potential for this type of tourism should be identified and used in regional planning. Choosing the right method among the many methods that have been developed by the researchers can be misleading if the path to the right research is not chosen. In geoscience, the role of geographic information system becomes increasingly colorful day by day. The significance of this is because it gives us a real perception of the environment, and the inputs and outputs are tangible. In this tool, some special complexities need to be recognized for its more effective use, which is being updated day by day.

Since ecotourism activities should be developed in zones with ecotourism potential of developing this land use, thus ecotourism potential evaluation using FAHP and TOPSIS model in GIS environment was chosen as the main methodology of this article. Accordingly, zones that ecologically have the potential of ecotourism development were identified in Marivan using 15 criteria derived from theoretical studies. Then, using different functions and different fuzzy operators and weighted linear combination, location data layers were created and integrated, and multiple results of operators were compared and evaluated together, and zones were divided from very weak to very strong groups in terms of ecotourism potential. Continuous local-spatial decision-making method in the form of integration of TOPSIS-GIS-FAHP techniques as an efficient method of multi-criteria decision-making techniques and discrete spatial models could well explain the ecotourism potential in the region. As a result, the indices and the designed ecotourism model here could be used as a model for other cities of the 
country to assess the ecotourism potential and ecotourism zoning with continuous spatial model and methods within the MCDM framework combination in GIS. The methods used to overlay the layers use different operators to combine the corresponding cells. For example, the functionality of these operators can be used to generate different decision scenarios. These scenarios can provide a range of rigorous and easy decision-making. Indeed, the decision maker can use these tools to plan properly.

The results showed that given the natural attractions, history, etc., Marivan town has a significant potential for ecotourism development based on the techniques and methods of up-to-date evaluation that were used, where out of the total area of the city (3196 square kilometers), $151 \mathrm{~km}^{2}$ has a very high potential, and 513 $\mathrm{km}^{2}$, has a high potential. In general, an area of about $664 \mathrm{~km}^{2}$, equivalent to $21 \%$ of the city area has a suita- ble potential. The next zones have an area of 893,972 and $652 \mathrm{~km}^{2}$, respectively. Among the ecotourism attractions, which included 17 cases, respectively Zarivar Lake, Ouramanat and Darband Dezli have claimed ranks 1 to 3, while Negel village, Ney heights, and Anjiran heights claimed ranks 15 to 17 . On a large scale, the city of Marivan, due to its location in the dry region of the Middle East, and the middle scale, is located in the Zagros region, resulting from specific climatic and geographical factors. Therefore, it has a high potential in ecotourism. The results of this modeling suggest that Zarivar Lake is considered to be the most important tourist attraction in terms of its unique features. In general, because of being in a dry area, water phenomena play a more significant role in tourism. The forest cover of the region, which is itself the result of the same climatic and regional conditions, has added to the tourism level of the region.

\section{References}

Affisco, J. F., \& Chanin, M. N. (1988, March). An empirical investigation of integrated spatial-proximity MCDM-behavioral problem solving technology group decision models. In Developments in Business Simulation and Experiential Learning: Proceedings of the Annual ABSEL conference (Vol. 15).

Amadi, A. A., \& Mozaffari., H. (2012). Analysis of Appropriate Zones for Ecotourism Development in Zanjan Province Using GIS. Geographical Research Quarterly, 27(3), 135-150.

Ananda, J., \& Herath, G. (2008). Multi-attribute preference modelling and regional land-use planning. Ecological economics, 65(2), 325-335.

Atasoy, M. (2010). Monitoring land use changes in tourism centers with GIS: Uzungöl case study. Scientific Research and Essays, 5(8), 790-798.

Azar, A., \& Faraji, H. (2008). Fuzzy management science. Tehran: IMPSC.

Badri, S. A., Rahmani, K., Qeydari, M. S., \& Poor, O. H. (2011). Strategies of ecotourism development in Marivan township. Rural Research, 2(6), 31-54.

Banerjee, U. K., Kumari, S., Paul, S. K., \& Sudhakar, S. (2002). Remote Sensing and GIS based ecotourism planning: A case study for western Midnapore, West Bengal, India. Map Asia. http://www. GIS development.net/ application miscellaneous/ miseo28 pdf. htm.

Bin, L., Suocheng, D., \& Mei, X. (2008). Ecotourism Model and Benefits of Periphery Regions in Western Sichuan Province. Chinese Journal of Population Resources and Environment, 6(2), 80-86.
Bonham-Carter, G. F. (1991). Geographic Information System for Geoscientists: Modeling with GIS, Ontario: Pergamon, pp. 291-300.

Brown, F. (2000). Tourism Reassessed: Blight or Blessing, New York: Routledge.

Bunruamkaew, K., \& Murayam, Y. (2011). Site suitability evaluation for ecotourism using GIS \& AHP: A case study of Surat Thani province, Thailand. Procedia-Social and Behavioral Sciences, 21, 269-278.

Butler, R. W. (2000). Ecotourism-has it achieved maturity or has the bubble burst. Keynote address. $\mathrm{Pa}$ cific Rim Tourism.

Cetin, M., \& Sevik, H. (2016). Evaluating the recreation potential of Ilgaz Mountain National Park in Turkey. Environmental monitoring and assessment, 188(1), 52.

Chang, D. Y. (1996). Applications of the extent analysis method on fuzzy AHP. European journal of operational research, 95(3), 649-655.

Deng, H., Yeh, C. H., \& Willis, R. J. (200o). Inter-company comparison using modified TOPSIS with objective weights. Computers \& Operations Research, 27(10), 963-973.

Drums, A., \& Moore, A. (2009). Introduction to Program Planning and Management Ecotourism; translation Ranjbar, First Edition. Ayizh Publishing

Edgell, D., DelMastro Alen, M., \& Swanson, J. (2008). Tourism Policy and Planning: Yesterday. Today and Tomorrow, First Edition, London.

Eftekhari, A. R., Qeidari, H. S., Purtaheri, M., \& Azar, A. (2013). Application of integration multi-criteria decision making method and GIS in identification of rural regions with ecotourism potential 
case study: river valley tourism in Tehran Providence. Rural Research, 4(3), 641- 660.

Eisavi, V., Karami, J., Alimohammadi, A., \& Niknezhad, S. A. (2012). Comparison the AHP and FUZZY-AHP Decision Making Methods in Underground Dam Site Selection in Taleghan Basin. Geosciences, 22(85), 27-34.

Faraji Sabokbar, H. (2005). Site selection for commercial service units by Analytical Hierarchy Process (AHP), Journal of Geography Researches, 37(51), 125138. (In Persian)

Fennell, D. (2003). Ecotourism. London, and New York: Routledge

Fung, T., \& Wong, F. K. (2007). Ecotourism planning using multiple criteria evaluation with GIS. Geocarto International, 22(2), 87-105.

Gthinji, M. W. (2006). An evaluation of the use of ecolabeling within the eco-tourism sector. Norwich: University of East Anglia

Gül, A., Örücü, M. K., \& Karaca, Ö. (2006). An approach for recreation suitability analysis to recreation planning in Gölcük Nature Park. Environmental management, 37(5), 606-625.

Hall, C. M. \& Page, S. J., (2002). The geography of tourism and recreation: Environment, place and space. London and New York: Routledge.

Harun, N., \& Samat, N. (2016). GIS-Based Multicriteria Evaluation Approach in Planning Tourism Development Sites in Environmentally Sensitive Areas. In SHS Web of Conferences (Vol. 23, p. 02001). EDP Sciences.

Hoang, H., Truong, Q., Nguyen, A., \& Hens, L. (2018). Multicriteria Evaluation of Tourism Potential in the Central Highlands of Vietnam: Combining Geographic Information System (GIS), Analytic Hierarchy Process (AHP) and Principal Component Analysis (PCA). Sustainability, 10(9), 3097.

Hwang, C.L. \& Yoon, K. (1981). Multiple Attribute Decision Making Methods and Applications, A Stateof-the-Art Survey. New York: Springer-Verlag.

Jeong, J. S., García-Moruno, L., Hernandez-Blanco, J., \& Sanchez-Rios, A. (2016). Planning of rural housings in reservoir areas under (mass) tourism based on a fuzzy DEMATEL-GIS/MCDA hybrid and participatory method for Alange, Spain. Habitat International, 57, 143-153.

Karami, O; Mahdavi, A.; Hosseininasr, M.; \& Jalilvand, H. (2014). Evaluation of Ecotourism prone areas using Analytical Hierarchy Process (AHP) (Case Study: Babolrood watershed, Mazandaran). Journal of Research Science and Technology Wood and Jungle, 21(2), 185- 202.

Keshavarz, A., Khashei Seoki, AS., Najafi, M. (2014). Proper siting of drinking water extraction using fuzzy AHP. Case study: Birjand aquifer. Water and Sanitation Quarterly, 3, 135 - 142.

Kourepazan Dezfooli, A. (2008). Principles of fuzzy sets theory and its application in modeling water engineering issues, Tehran: SID publishing

Kumari, S., Behera, M. D., \& Tewari, H. R. (2010). Identification of potential ecotourism sites in West District, Sikkim using geospatial tools. Tropical Ecology, 51(1), 75-85.

Lai, Y. J., Liu, T. Y., \& Hwang, C. L. (1994). Topsis for MODM. European journal of operational research, 76(3), 486-500.

Laurance, W. F., Alonso, A., Lee, M., \& Campbell, P. (2006). Challenges for forest conservation in Gabon, Central Africa. Futures, 38(4), 454-470.

Li, K. (2008). SWOT Analysis and Model Discussion of China's Tourism Resources Development-Xiangxi Autonomous Prefecture in Hunan Province as an example. Forestry Economics, 6, 74-76.

Lin, H. T. (2010). Fuzzy application in service quality analysis: An empirical study. Expert systems with Applications, 37(1), 517-526.

Lu, J., \& Ruan, D. (2007). Multi-objective group decision making: methods, software and applications with fuzzy set techniques (Vol. 6). Imperial College Press.

Maghsoudi, M., Faraji Sabokbar, H., Parvaz., H., Behnam Morshedi, H. (2015). Locating optimal areas for ecotourism development in Kavir National Park using GIS and genetic algorithms. Human Geography Research, (47)2, 367-390.

Malczewski, J. (1999). GIS and multicriteria decision analysis. London: Wiley.

Malczewski, J. (2004). GIS-based land-use suitability analysis: a critical overview. Progress in planning, 62(1), 3-65.

Malek, M. R., Hemmati, F., Jahedi, N., \& Fardad, M. (2011). Optimal location of fire stations sampling using network analysis, fuzzy logic and GIS. Tehran: Hmayeshe Geomatics, National Cartographic Center.

Minciardi, R., Paolucci, M., Robba, M., \& Sacile, R. (2008). Multi-objective optimization of solid waste flows: Environmentally sustainable strategies for municipalities. Waste Management, 28(11), 22022212.

Miri, S. S. (2011). Analysis of the tourism of Ouramanat area (with an emphasis on the feasibility of tourist areas) using Topsis, Paveh Case Study., Master thesis, University of Sistan and Baluchestan.

Moradzadeh, F., Moosazadeh Abbasi, N., Moshashaei, S. M. (2011). New model in ranking and financial evaluation of companies (Case Study: Tehran Stock Exchange base metals industry). Accounting and Auditing Investigation Quarterly, 66, 41-52. 
Nyaupane, G. P., \& Thapa, B. (2004). Evaluation of ecotourism: A comparative assessment in the Annapurna Conservation Area Project, Nepal. Journal of Ecotourism, 3(1), 20-45.

Olson, D. L. (2004). Comparison of weights in TOPSIS models. Mathematical and Computer Modelling, 40(7-8), 721-727.

Opricovic, S., \& Tzeng, G. H. (2004). Compromise solution by MCDM methods: A comparative analysis of VIKOR and TOPSIS. European journal of operational research, 156(2), 445-455.

Papageorgiou, M. (2016). Coastal and marine tourism: A challenging factor in Marine Spatial Planning. Ocean \& coastal management, 129, 44-48.

Parolo, G., Ferrarini, A., \& Rossi, G. (2009). Optimization of tourism impacts within protected areas by means of genetic algorithms. Ecological Modelling, 220(8), 1138-1147.

Phua, M. H., \& Minowa, M. (2005). A GIS-based multi-criteria decision making approach to forest conservation planning at a landscape scale: a case study in the Kinabalu Area, Sabah, Malaysia. Landscape and urban planning, 71(2-4), 207-222.

Pourtaheri, M. (2011). Multi-criteria decision-making methods in geography, Samt publishing.

Ramsey, M., \& Schaumleffel, N. A. (2006). Agritourism and rural economic development. Indiana Business Review, 81(3), 6-9.

Rao, R. V., \& Davim, J. P. (2008). A decision-making framework model for material selection using a combined multiple attribute decision-making method. The International Journal of Advanced Manufacturing Technology, 35(7-8), 751-760.

Salam, M. A., Lindsay, G. R., \& BEVERIDGE, M. C. (2000). Eco-tourism to protect the reserve mangrove forest the Sundarbans and its flora and fauna. Anatolia, 11(1), 56-66.

Safari, A. A. (2012). Comparison of the frequency ratio and fuzzy membership functions in zoning landslide hazard (Case Study: Sanandaj-Marivan road),
Journal of Geography and Environmental Hazards, 4, 79- 96.

Sharifi, M., \& Bastani, A. (2015). Ecotourism zoning using fuzzy model, Case study: Shiraz city. Geographical Planning of Space Quarterly Journal, 5(16), 127-150. (In Persian).

Stankov, U., Klaučo, M., Dragićević, V., Vujičić, M. D., \& Solarević, M. (2016). Assessing land-use changes in tourism area on the example of Čajetina municipality (Serbia). Geographica Pannonica, 20(2), 105113.

Stankov, U., Stojanović, V., Dragićević, V., \& Arsenović, D. (2011). Ecotourism-An alternative to mass tourism in nature park "Stara Planina". Journal of the Geographical Institute "Jovan Cvijić, 61(1), 43-59.

Tavana, M., \& Hatami-Marbini, A. (2011). A group AHP-TOPSIS framework for human spaceflight mission planning at NASA. Expert Systems with Applications, 38(11), 13588-13603.

Thampi, S. P. (2005). Ecotourism in Kerala, India: Lessons from the eco-development project in Periyar Tiger Reserve. ECOCLUB.

Tremblay, P. (2006). Desert tourism scoping study. Desert Knowledge CRC.

Tsaur, S. H., \& Wang, C. H. (2007). The evaluation of sustainable tourism development by analytic hierarchy process and fuzzy set theory: An empirical study on the Green Island in Taiwan. Asia Pacific Journal of Tourism Research, 12(2), 127-145.

Wang, Y. J. (2008). Applying FMCDM to evaluate financial performance of domestic airlines in Taiwan. Expert Systems with Applications, 34(3), 18371845 .

Wearing, S., \& Neil, J. (1999). Ecotourism: Impacts, Potentials and Possibilities. Reed Educational and Professional Publishing Ltd.

Weaver, D. B., \& Lawton, L. J. (2007). Twenty years on: The state of contemporary ecotourism research. Tourism management, 28(5), 1168-1179. 